\title{
Over verrassende en soms ernstige gevolgen van een excellente internistenopleiding
}

Citation for published version (APA):

Koopmans, R. P. (2007). Over verrassende en soms ernstige gevolgen van een excellente internistenopleiding. Maastricht University. https://doi.org/10.26481/spe.20071019rk

Document status and date:

Published: 19/10/2007

DOI:

10.26481/spe.20071019rk

Document Version:

Publisher's PDF, also known as Version of record

\section{Please check the document version of this publication:}

- A submitted manuscript is the version of the article upon submission and before peer-review. There can be important differences between the submitted version and the official published version of record.

People interested in the research are advised to contact the author for the final version of the publication, or visit the DOI to the publisher's website.

- The final author version and the galley proof are versions of the publication after peer review.

- The final published version features the final layout of the paper including the volume, issue and page numbers.

Link to publication

\footnotetext{
General rights rights.

- You may freely distribute the URL identifying the publication in the public portal. please follow below link for the End User Agreement:

www.umlib.nl/taverne-license

Take down policy

If you believe that this document breaches copyright please contact us at:

repository@maastrichtuniversity.nl

providing details and we will investigate your claim.
}

Copyright and moral rights for the publications made accessible in the public portal are retained by the authors and/or other copyright owners and it is a condition of accessing publications that users recognise and abide by the legal requirements associated with these

- Users may download and print one copy of any publication from the public portal for the purpose of private study or research.

- You may not further distribute the material or use it for any profit-making activity or commercial gain

If the publication is distributed under the terms of Article $25 \mathrm{fa}$ of the Dutch Copyright Act, indicated by the "Taverne" license above, 
Over verrassende en soms ernstige gevolgen van een excellente internistenopleiding 


\section{Colofon}

Ontwerp en print: Océ Business Services, Maastricht

ISBN: 978-90-5681-275-1

NUR: 870

Alle rechten voorbehouden. Niets uit deze uitgave mag worden verveelvoudigd, opgeslagen in een geautomatiseerd gegevensbestand of openbaar gemaakt worden, zonder voorafgaande schriftelijke toestemming van de auteur of uitgever. 


\section{Over verrassende en soms ernstige gevolgen van een excellente internistenopleiding}

Oratie van Richard Koopmans, 19 oktober 2007

Universiteit Maastricht 

Geachte Rector Magnificus, geachte decaan, beste collegae, vrienden, familie en genodigden,

Opleiding en onderwijs staan zo in de belangstelling dat je kunt spreken van een rage, of in modern Nederlands een hype. Waarom is dat eigenlijk zo? Als het gaat om universitair en postacademisch onderwijs (mijn vak en het onderwerp van vandaag) spelen zowel ideële als wat meer stoffelijke motieven een rol. Om met het laatste te beginnen: medische opleidingen zijn heel duur, en ze duren nogal lang, zodat er dus alle reden om na te denken over de efficiëntie ervan. Om u een idee te geven: het opleiden van een medisch student kost circa 30.000 Euro per jaar, een medisch specialist opleiden kost ongeveer 100.000 Euro per jaar; beide opleidingen duren 6 jaar, zodat een volledig opgeleide medisch specialist vanaf zijn eindexamen middelbare school in 12 jaar tijd bijna 1 miljoen Euro heeft gekost. Niet alleen moet dat geld goed besteed worden, namelijk aan efficiënte opleidingen, maar die opleidingen moeten natuurlijk ook een voor iedereen acceptabele afgestudeerde opleveren, de moderne medisch specialist. De beroepsgroep van medisch specialisten, waar ik deel van uitmaak, staat dan ook in het brandpunt van publieke belangstelling en wij willen dus graag laten zien dat we meegaan met de tijd. De universiteit Maastricht vindt medische opleidingen ook van groot belang. En zodoende sta ik hier voor $u$, benoemd tot hoogleraar algemeen interne geneeskunde, in het bijzonder het onderwijs en de opleiding daarin. Ik hoop $u$ in de komende 45 minuten duidelijk te kunnen maken wat ons in de komende jaren op dit gebied te doen staat.

\section{Hoe word je een expert?}

Een inhoudelijke reden om na te denken over deze vorm van volwassenenonderwijs is de ontwikkeling van de wetenschap die zich bezighoudt met het leren van mensen. Ik ga $u$ daar direct meer over vertellen. Deze nieuwe inzichten pogen wij inmiddels tevertalen in opleidingsprog ramma's die aansluiten bij de theorie, en die dus zouden moeten 'werken'. U zult begrijpen dat dit wetenschap betreffende menselijk gedrag is. Dat is een tak van wetenschap die veel moeilijker is dan de gewone biomedische wetenschap die het ontstaan en de behandeling van ziekten bestudeert, al was het maar omdat we bij onderzoek naar leren in zekere zin onszelf bestuderen. Afgezien van de methodologische aspecten, raakt dit onderzoek ook steeds aan politiek en ethiek. 
Wat is er nu de afgelopen jaren bekend geworden over het leren van volwassenen. De Zweeds-Amerikaanse psycholoog Ericsson heeft de theorie van het bewust oefenen gelanceerd en inmiddels goed onderbouwd als de theorie over het ontwikkelen van expertise [1]. In het Engels heet deze theorie deliberate practice [2]. Deze theorie lijkt op allerlei terreinen van leren in overeenstemming met de feiten, van sport tot muziek tot het ontwikkelen van expertise op medisch gebied. Deze theorie gaat er vanuit dat aanleg bij alle expertiseontwikkeling wel een zekere rol speelt, maar dat de hoofdrol bij de evolutie van beginner tot expert wordt gespeeld door gericht oefenen. Bij nadere analyse van succesvolle musici en sporters blijkt dat het nooit is voorgekomen dat iemand via aanleg 'zomaar' tot een hoog niveau is gekomen. Neen, zonder uitzondering hebben mensen die heel goed zijn geworden in een complexe taak circa 10.000 uur geoefend. Aanleg geeft hierop geen korting, maar misschien wordt het uiteindelijk bereikte niveau er wel door beïnvloed. Misschien ook niet. Het cruciale punt is hoe die 10.000 uur worden besteed. Het is absoluut noodzakelijk om gericht te onderkennen wat je nog niet goed kunt en daar aan te gaan werken. Het is dan ook in het geheel niet voldoende om die 10.000 uur gewoon met het vak bezig te zijn, nee het moet gericht oefenen zijn. Zo zijn er natuurlijk mensen die een vak op hobbyniveau beoefenen, en die niet gericht werken aan zwakheden; zij komen nooit tot een hoog niveau. Om die 10.000 uur zinvol bezig te kunnen blijven zijn 2 dingen nodig: een sterke motivatie (die ook door alle succesvolle mensen wordt genoemd als de beslissende factor in hun succes), en een leermeester die de leerling wijst op zijn huidige zwakke plekken en ook expliciet technieken aanleert die effectief zijn om die zwakke plekken tot sterke punten te maken. Dus: oefenen, oefenen, oefenen. Deze oefening is verreweg het effectiefst als die deels in een oefensetting, en deels in de echte praktijk plaatsvindt. Daarmee kan vrijwel iedereen heel erg ver komen, verbluffend ver. Een aardig voorbeeld is een experiment dat u zult herkennen. Bij een test wordt u gevraagd een rijtje willekeurige cijfers die u worden voorgelezen te reproduceren. De meeste mensen komen tot circa 8. Het blijkt nu voor ieder mens mogelijk door gericht te oefenen (geen 10.000 uur), en met name door trucjes te leren tot 80 te komen. Deze proefpersonen hadden helemaal geen bijzonder geheugen. Hoe kun je het nu opbrengen om zo langdurig en gericht te oefenen? Is die motivatie wellicht meetbaar aan het begin van een carrière? Op deze vragen is nog geen wetenschappelijk antwoord. 


\section{Hoe zit de internistenopleiding in elkaar?}

Ik ga het nu hebben over de medische opleidingen, in het bijzonder die van internist. Om die opleiding te begrijpen is het nodig iets over de historie ervan te weten. Dokters zijn er in enigerlei vorm altijd geweest. Volgens gedragswetenschappers heeft dit wortels in een unieke menselijke eigenschap: het zelfbewustzijn, die op zich weer de basis vormt voor altruïsme. Natuurlijk was de dokter uit vroeger tijden ook een soort magiër, een heel andere wortel van de moderne geneeskunde, en deze wortel is ook nog steeds van niet onaanzienlijk belang. Voorts heeft de moderne dokter sinds de $19^{\mathrm{e}}$ eeuw wortels in de natuurwetenschappen. Deze drie, altruïst, magiër en natuurwetenschapper, alle drie zijn ze nog steeds relevant. $U$ begrijpt dat de opleiding voor een dergelijk vak een nogal sterke evolutie heeft doorgemaakt. Vanouds kon je dit vak op twee manieren leren. Door bij een erkende vakman (vroeger erkende magiër) in de leer te gaan; leren in de praktijk dus; meedoen en nadoen; de kunst afkijken. Vanaf de renaissance bestond er ook een vrijwel volledig theoretische studie op de universiteit. Met name in de $19^{\mathrm{e}}$ eeuw zijn daar de natuurwetenschappen bijgekomen, en zijn de twee manieren om het vak te leren samengevoegd, zodat je nu medisch specialist wordt door 6 jaar basisgeneeskunde te studeren, de eed af te leggen, en daarna $-u$ raadt het al -3 tot 6 jaar in de leer te gaan om je te specialiseren. Daarbij ben je in de leer bij een leermeester, die heet tegenwoordig de opleider, en zelf ben je de ouderwetse gezel, die heet tegenwoordig aios, en dat betekent arts in opleiding tot specialist. Tijdens mijn verhaal zal ik enigszins simplificeren door het over de opleider hebben in enkelvoud, in de praktijk is dit allang een team van specialisten waarvan de opleider het hoofd is. Als het over de aios gaat zeg ik hij, maar dat betekent natuurlijk niet dat dit altijd mannen betreft: het zal $u$ allen bekend zijn dat sinds de jaren vijftig van de vorige eeuw het percentage vrouwen dat dokter en medisch specialist wordt fors en gestaag groeit. Inmiddels is in alle medische studies overal ter wereld minstens de helft van de studenten vrouw.

Om mijn wellicht wat abstracte verhaal te verduidelijken zal ik beginnen met u een voorbeeld geven. De aios interne geneeskunde doet zelfstandig polikliniek en ziet een jonge vrouw met bloedarmoede door ijzertekort. Meestal zal de huisarts een dergelijke patiënte zelfstandig kunnen behandelen, maar in dit geval heeft hij de patiënte doorgestuurd omdat hij het niet vertrouwt. Moet er niet toch een onderzoek van de dikke darm worden gedaan om te bezien of daaruit bloedverlies 
plaatsvindt? Onze aios legt een dossier aan van de patiënte, waarin gegevens over haar klachten, het lichamelijk onderzoek, zijn mening over de mogelijke oorzaak van het ijzergebrek en zijn voorstel voor verder onderzoek en behandeling. De aios spreekt deze behandeling van $A$ tot $Z$ door met de opleider. Soms, maar niet altijd, zal de opleider ook nog zelf de patiënte zien of onderzoeken. Op deze wijze behandelt onze aios interne geneeskunde 10-20 patiënten per dag. Niet alleen op de polikliniek, maar ook patiënten die opgenomen zijn op de afdeling interne geneeskunde, patiënten die zich met acute ziekten melden op de spoedeisende hulp, en patiënten van andere specialisten waar men een advies van een internist over wil hebben. Onze aios heeft meestal een drukke werkdag waarbij zelfstandig werken constant wordt afgewisseld met overleg met de opleider. Regelmatig heeft onze aios één of twee weken avond- en nachtdienst, waarbij hij verantwoordelijk is voor de patiënten die met een acute ziekte naar het ziekenhuis komen, en voor opgenomen patiënten die onmiddellijke aandacht nodig hebben. Wat moet deze aios nu allemaal leren, en moet dat 6 jaar duren?

In ieder geval moet onze aios veel praktische kennis over ziektes opdoen. Bovendien moet hij technische vaardigheden leren: niet alleen een gesprek voeren, en een goed lichamelijk onderzoek doen, maar ook leren omgaan met allerlei apparatuur die in ziekenhuizen wordt gebruikt, en heel specifieke vaardigheden zoals bijvoorbeeld een botpunctie om beenmerg te verkrijgen voor nadere analyse van een anemie. Wat betreft de jonge vrouw met bloedarmoede: misschien is zij wel een asielzoekster uit Afrika die geen Nederlands spreekt, waarbij haar echtgenoot als tolk optreedt, en waarbij direct blijkt dat zij eigenlijk ontevreden is met het feit dat de aios een man is, en waarbij tevens blijkt dat zij geen endoscopie (inwendig onderzoek van de darm) wenst. Onze aios moet ook hiermee leren omgaan. Tegenwoordig spreken we over kennis, vaardigheden, en attitude. Het laatste begrip heet ook wel professionaliteit, de beroepshouding, de wijze waarop de specialist zijn vak uitoefent in de breedste zin des woords. Wij komen nu bij de kern van de zaak: hoe kun je dit allemaal leren. En hoe maak je een internistenopleiding die voorwaar excellent is?

\section{Wat is een goede opleider van medisch specialisten?}

I $\mathrm{k}$ wil met $\mathrm{u}$ eerst eens nadenken wat een internistenopleiding goed maakt. Op het eerste gezicht is het antwoord eenvoudig: daar waar de beste opleider zit, is ook de beste opleiding. OK, maar wat is dan 
de beste opleider? Een criterium zou kunnen zijn dat deze opleider wetenschappelijk vooraanstaand is, en liefst dat hij nieuwe methoden heeft ontdekt om ziekten vast te stellen of te behandelen. $U$ zult het met mij eens zijn dat dit criterium zonder meer van groot belang is, omdat de aios zo tijdens zijn opleiding kennis maakt met het beste wat er op zijn vakgebied is. Zowel in het verleden als nu speelde en speelt dit criterium dan ook een grote rol. Het leidt bijvoorbeeld vaak tot schoolvorming. Leerlingen van een wetenschappelijk vooraanstaande specialist gaan dan na hun opleiding elders in de zin van de grote meester de traditie voorzetten. Voorbeelden hiervan zijn de Amsterdamse internist prof Borst, en de eveneens Amsterdamse cardioloog prof Durrer, die op deze wijze de Nederlandse geneeskunde sterk hebben beïnvloed. Deze manier van vooraanstaand opleiden is tegenwoordig moeilijker omdat het uitwisselen van informatie zo enorm gemakkelijk is geworden. Wat tot misschien wel in de jaren zeventig van de vorige eeuw kon, namelijk dat je zelf iets in huis had dat elders niet bestond (ik doel uiteraard op nieuwe geneesmethoden), bestaat nu vrijwel niet meer omdat methoden en technieken zich razendsnel verplaatsen van de ene kliniek naar de andere. We leven immers in de informatiemaatschappij, waar de dokter bovendien nog eens wordt gedwongen al zijn vindingen zo snel mogelijk via de medische literatuur openbaar te maken. Laten we dus nog eens een ander criterium van excellent opleiderschap bezien.

Tegenwoordig wordt dan een parallel getrokken met voetballen of vioolspelen. En indachtig wat ik $u$ net heb verteld over het gericht oefenen is dat ook helemaal nog niet zo gek. De excellente opleider wordt dan zoiets als een heel goed coach of pedagoog, die het beste uit zijn leerlingen weet te halen. De aios neemt als het ware lessen bij de opleider, en de opleider helpt onze aios zich zo te ontwikkelen dat hij een uitstekend vakman wordt. I hoop dat $\mathrm{u}$ het met mij eens bent dat onze ideale opleider niet alleen kennis over ziekten en hun behandeling bij onze aios moet bevorderen. Bij de net genoemde patiënte met bloedarmoede is dat evident: alleen kennis over bloedarmoede zal geheel onvoldoende zijn om deze patiënte op professionele wijze van medisch advies te voorzien. Het grote probleem bij het net genoemde criterium van opleiderschap is dus - evident als we het vergelijken met voetballen en vioolspelen - dat het niet direct duidelijk is welk gedrag we nu precies bij onze aios moeten vormen. Als we er verder over denken gaat dit overigens ook wel op voor voetballen of vioolspelen: iedere pedagoog of trainer houdt er zeer evident heel eigen opinies op na over wat goed is. Het resultaat, de goede voetballer of violist is echter direct 
voor iedere leek herkenbaar; bij de excellente specialist is dat veel minder zo. Natuurlijk is er inmiddels veel nagedacht over de eigenschappen die onze opleider/coach zou moeten bevorderen bij de aios: deze moet voor alles een expert op medisch gebied zijn, daarnaast goed kunnen communiceren met patiënten, goed kunnen samenwerken met zijn collegae, hij moet op een verstandige en acceptabele manier moeilijke beslissingen kunnen nemen, en bij dit alles dient hij behalve het belang van zijn patiënt ook het maatschappelijk belang in zekere mate in het oog te houden. Onze opleider heeft heel wat te coachen op deze manier! De goede opleider wordt een soort mengeling van psycholoog, coach en dokter. Hier mag hij op zijn beurt wel wat op oefenen om dat te laten lukken. Laten we dus nog maar eens verder kijken.

Een criterium voor de goede opleider is bij ook uitstek of deze als persoon en als specialist een voorbeeldfunctie heeft. Hiernaar is veel onderzoek gedaan, en we weten vrij nauwkeurig in welke dokters aios een voorbeeld zien [3]. Deze voorbeelden, tegenwoordig rolmodellen genoemd, besteden bij uitstek aandacht aan de psychosociale aspecten van de arts-patient relatie, zij nemen veel tijd om aan de aios van alles uit te leggen, en de begeleiding van de aios vindt plaats in een veilig klimaat. De wetenschappelijk kwaliteiten van een specialist dragen helemaal niets bij aan het zijn van rolmodel; uiteraard alles door de ogen van de aios. Deze rolmodellen tref je dus vooral aan onder de gedreven practici. Het effect van een goed voorbeeld is dat het motiverend werkt, onder andere omdat het laat zien wat mogelijk is. Er zitten natuurlijk ook nadelen aan het volgen van dergelijke ideaalbeelden. Een leerling leert waarschijnlijk efficiënter door zich op de eigen zwakke en sterke zijden te concentreren, dan op de vooral van buiten gepercipieerde sterke zijden van een ideaalbeeld.

Welke van de drie opleidersmodellen moeten we nu kiezen om de excellente internistenopleiding te gaan maken? Eerlijk gezegd, ik weet het niet, maar de opleiders zelf hebben het eerste in het hoogste aanzien (de vooraanstaande wetenschapper en schoolvormer), de tijdgeest kiest voor het tweede model (de coach), terwijl de aios vooral kiezen voor het laatstgenoemde beeld van de vriendelijke en gedreven practicus.

\section{Hoe ziet een goed opleidingsprogramma eruit?}

We zijn er natuurlijk ook nog niet natuurlijk. Een goede school heeft niet alleen goede docenten maar ook een goed en modern lesprogramma. De medische tijden veranderen in veel opzichten nogal snel. Onze excellente 
opleiding moet natuurlijk meeveranderen. Om u te schetsen wat er zoal aan moderniteit in onze moderne opleiding moet komen wil ik even met u terug naar 1983, het jaar waarin ik voor het eerst werkte als aios.

Er waren toen nog niet overal computers; de universiteit had een computer die met ponskaarten werd bediend. Omdat er vrijwel geen computers waren was er geen internet, waren er geen röntgenfoto's die met computers worden gemaakt (CT-scans), en patiëntgegevens waren vaak niet snel beschikbaar. De aios werkten nog niet in ploegendienst; gewerkte avonden, nachten en weekenden werden niet met vrije tijd gecompenseerd maar de aios deden deze erbij; hun werkweek was daardoor veel langer dan nu, inclusief avond- en nachtdiensten meer dan 60 uur. Daardoor had de patiënt wel veel vaker langere tijd dezelfde dokter, maar vermoeidheid door zeer lange werkdagen was een probleem voor de aios. Patiënten lagen voor dezelfde aandoening wel 2 keer zo lang in het ziekenhuis als tegenwoordig omdat er (blijkbaar) geen tekort aan paramedici was. Ziekenhuizen waren in het algemeen kleiner en het management speelde een minder voelbare rol dan nu. Medischinhoudelijk is de geneeskunde sinds 1983 ook enorm veranderd, zo bestond de ziekte AIDS toen bijvoorbeeld nog niet [4]. De patiënten zijn ook langzamerhand veranderd: er zijn steeds meer oudere mensen met verschillende ziekten tegelijkertijd gekomen; in alle leeftijdscategorieen speelt preventieve geneeskunde een sterkere rol. Hoe verwachten wij nu dat excellente medische opleidingen, bijvoorbeeld de opleiding tot internist, hierop zijn opleidingsprogramma zou moeten aanpassen?

De computer is natuurlijk maar een ding, maar met dit ding is er permanente toegang tot informatie gekomen. Parate kennis is nog steeds van groot belang, maar het bijhouden van medische literatuur door het lezen van oorspronkelijke stukken is niet meer mogelijk: men heeft uitgerekend dat als je 5 wetenschappelijke artikelen per dag zou lezen (een op zich al grote prestatie), dan liep je na 1 jaar reeds 20 eeuwen achter! Natuurlijk wil je echter niet alles lezen, maar alleen dat wat je nodig hebt. Bovendien zijn er nu overal handige samenvattingen van medische literatuur te vinden die soms ook heel praktisch vertaald zijn naar richtlijnen. Die moet je dus kunnen vinden, lezen, en gebruiken. Verder moet onze aios heel handig zijn met allerlei computerprogramma's zoals het elektronisch patientendossier, computerprogramma's om medicijnen voor te schrijven, en moet hij met behulp van de computer voordrachten leren houden. Over het algemeen kun je constateren dat specialistenopleidingen hier redelijk wat aandacht aan zijn gaan besteden. 
Het werken in ploegendienst en het kortere verblijf van de patiënt in het ziekenhuis hebben er samen voor gezorgd dat de aios in 2007 een heel veel drukkere werkdag heeft dan in 1983. Veel informatie over de patiënten die de aios vandaag behandelt heeft hij uit de tweede hand, via overdracht gekregen. Met die informatie moet onze aios in 2007 in veel kortere tijd een programma afwerken om tot een goede diagnose en behandeling te komen. Als u ooit patiënt bent geweest kent $u$ het uit eigen ervaring: $u$ hebt tijdens een verblijf in het ziekenhuis of tijdens polikliniekbezoeken steeds een andere dokter, met name in grote opleidingsziekenhuizen zoals bijvoorbeeld de academische ziekenhuizen. Het lijkt erop dat de medische opleidingen op dit punt nog onvoldoende met hun tijd meegegaan. Efficiënt indelen van de werkdag, hoe je het beste in een team kunt werken, hoe je het beste informatie kunt overdragen, hoe je met stress moet omgaan, medische opleidingen doen er over het algemeen weinig aan, en dat is geen onwil, maar er zijn eenvoudigweg nog nauwelijks onderwijsmethoden voor ontwikkeld. Het is niet geheel onmogelijk dat er soms voor zowel de patiënten als de aios zelf problemen ontstaan door deze hectiek van de moderne ziekenhuizen. Zo was er recent een onderzoek waaruit bleek dat een relatief groot aantal aios zou leiden aan burn-out (dat wil zeggen, een scala van klachten dat ontstaat door te hoge werkdruk) [5].

De oudere mensen met verschillende ziekten tegelijkertijd zijn nu eerder de norm dan de uitzondering in onze ziekenhuizen. Ik geef u een voorbeeld. Een patiënt met suikerziekte heeft vaak ook een hartziekte, minder goed functionerende nieren, problemen met zien, en slecht genezende wonden aan de benen. Vaak heeft een dergelijke cumulatie van aandoeningen een depressie tot gevolg. Vaak blijkt deze patiënt ook nog botontkalking en hoge bloeddruk, symptoomloze aandoeningen die preventief behandeld worden. Deze patiënt heeft al snel te maken met de huisarts, een internist gespecialiseerd in suikerziekte en een internist gespecialiseerd in nierziekten, de cardioloog, de oogarts en de psychiater. Al deze dokters doen een stukje van het medisch probleem en moeten dus samenwerken. Dat moeten zij leren als aios tijdens de opleiding tot specialist. Zij moeten er dus zorgen dat de patiënt niet een dagtaak heeft aan het aflopen van vele spreekuren, dat onze patiënt niet teveel medicijnen krijgt, dus dat er 1 zorgverlener is met een coördinerende rol. Deze coördinerende specialist moet in het belang van de patiënt, en uiteraard samen met de patiënt, keuzes kunnen maken. Buiten het ziekenhuis wordt dit gedaan door de huisarts. In het ziekenhuis hebben de zorgverleners hier moeite mee, en er zijn nog maar mondjesmaat 
modellen voor verbetering. Om u een aansprekend voorbeeld te noemen: recent had ik te maken met 2 bejaarde patiënten die respectievelijk 24 en 28 medicijnen innamen. Na analyse en goed afwegen bleek dat er voor 18 en 20 medicijnen een goede indicatie bestond. Het team van specialisten slaagde er niet in om dit aantal te reduceren, zodat de patiënten naar huis gingen met nog steeds te veel medicijnen. ledere specialist heeft hierbij professioneel adequaat en volgens zijn eigen richtlijn juist gehandeld, het totaal is helaas onacceptabel.

We hebben nu al veel ingrediënten om de ideale, excellente internistenopleiding in de steigers te zetten. Maar stop. Wat willen de patiënten eigenlijk, om hen gaat het tenslotte. Hoe raar het ook klinkt, hier is niet veel over bekend. Een patiënt is misschien ook wel een vreemde categorie, ze zijn natuurlijk even verschillend van elkaar als mensen überhaupt van elkaar verschillen. Door je oogharen kijkend en gokkend denk je dat de patiënt meestal een deskundige, maar ook aardige, toegankelijke en betrokken dokter wil. In Canada heeft men in de jaren negentig van de vorige eeuw gepoogd dit enigszins systematisch te onderzoeken, met - niet erg verrassend - het genoemde resultaat. Voor ons, opleiders in Nederland in 2007, is dit van groot belang, want wij zijn inmiddels in het hele land bezig onze specialistenopleidingen via dit Canadese systeem op moderne leest te schoeien. CANMEDS heet het, Canadese Medische Educatie voor Specialisten. Om precies te zijn heeft men daar vastgesteld dat de specialist behalve een goede medisch expert, ook goed moet zijn in samenwerken en organiseren, wetenschap, communicatie, professionaliteit, dat hij zijn werk maatschappelijk verantwoord moet doen.

\section{Naast een goede opleider en een goed opleidingsprogramma is ook het klimaat van belang}

De laatste factor die we nodig hebben bij het maken van de excellente internistenopleiding is wat wel genoemd wordt het opleidingsklimaat. In een excellente internistenopleiding is iedereen zich ervan bewust dat wij er zijn om al onze aios op te leiden tot een excellente specialist. ledereen, dat betekent portier, verpleegkundige, medisch specialist, afdelingshoofd en ziekenhuis-directeur. ledereen is er zich van bewust wat het betekent om iets te moeten leren: dat de aios erg gevoelig is voor datgene wat de anderen van hem vinden, en dat kritiek weliswaar soms hard aankomt, maar dat zij noodzakelijk is voor de ontwikkeling van de aios. Kritiek moet dus voortdurend, en zo expliciet en zo constructief als maar mogelijk 
worden gegeven. ledereen heeft een voorbeeldrol, elke bespreking en handeling in de kliniek geschiedt met in het achterhoofd dat deze vormend moet zijn voor de aios. ledereen in deze kliniek heeft dus ook een heel helder ideaalbeeld voor ogen van heel goede patiëntenzorg. Overigens, zullen de aios dat leuk vinden? Niet altijd denk ik. Zo expliciet in de positie van leerling te worden geplaatst is erg vervelend voor het ego. Als je onzeker bent is stoer doen een voordehandliggende reactie (fluiten in het donker noem je zoiets in goed Nederlands); de opleiders versterken dit effekt al snel door evident blij te zijn met een aios die vanaf dag 1 alles lijkt te kunnen als een ervaren kracht. Hier is erg veel onderzoek naar gedaan, en daar blijkt keer op keer uit dat medische opleidingen veel moeite hebben om een klimaat te scheppen waar constructieve kritiek regel is en geen uitzondering, en waar de staf een expliciete voorbeeldrol heeft. Ons opleidingsteam zal namelijk ook wel moeite hebben met dit ideale opleidingsklimaat. Van hen wordt een expliciete voorbeeldfunctie verwacht, en ze moeten elkaar daar op aanspreken. Zo komen hun eigen beperkingen en zwakheden al snel aan het licht. Misschien maken zij ook wel fouten en zijn er competenties die zij niet beheersen. Hun autoriteit komt dan al snel ter discussie.

\section{Welke veranderingen zijn er op dit moment gaande in de Nederlandse specialistenopleidingen, en welke gevolgen kunnen die hebben}

Ik begon mijn verhaal $u$ te vertellen dat opleiden een hype is. Door alle aandacht voor opleiding en onderwijs worden de specialistenopleidingen snel geprofessionaliseerd. Dat wil zeggen er komen steeds meer specialisten en hoogleraren die hier hun dagtaak van maken. Deze professionalisering heeft allerlei voor de hand liggende voordelen: je wordt goed in wat je vaak doet en datgene waarover je goed nadenkt. Deze zich snel ontwikkelende groep van specialist-onderwijzers brengt ook weer nieuwe risico's mee. Voor zover zij geen excellente clinici of excellente wetenschappers zijn, zullen zij vooral als coach en als organisator een rol kunnen spelen. Dit zijn natuurlijk bona fide taken. In de medische hiërarchie is echter een heel duidelijke pikorde aanwezig: bovenaan staan de excellente wetenschappers, dan komen de sterk gespecialiseerde clinici, daarna de breed georiënteerde clinici, en als laatste de onderwijzers. Onze specialist-onderwijzer bevindt zich meestal onder aan de pikorde van het ziekenhuis. Dit is bijzonder jammer voor het ego, maar dat is nog tot daar aan toe. Het beperkt echter in sterke mate de mogelijkheid van deze collegae om de operationele gang van zaken 
in het ziekenhuis aan te passen aan dat wat nodig is voor de excellente opleiding. Paradoxalerwijze zou het wel eens zo kunnen zijn, dat nu het opleiden geprofessionaliseerd is, dit de armslag van het opleidingsteam verkleint, omdat de specialisten die het grootste gewicht in de schaal van het ziekenhuis leggen er zich veel minder mee bemoeien. Het is dus noodzaak dat de geprofessionaliseerde onderwijzers hetzij hun legitimiteit behouden door andere activiteiten dan onderwijs, hetzij dat zij er op de een of andere wijze voor zorgen dat opleiding ook voor de niet-professionele onderwijzers erg belangrijk blijft.

Het opleidingsteam van de toekomst bestaat dus misschien wel niet meer uit specialisten die hun legitimiteit ontlenen aan hun status als wetenschapper of sterk gespecialiseerde dokter. Hierdoor zal het vak van medisch specialist mogelijk prestige verliezen. Het gaat meer lijken op de opleiding van paramedici. Reeds nu maak ik regelmatig discussies mee onder collegae met als onderwerp of onze internistenopleiding nu wel of niet een wetenschappelijk karakter heeft. Dit is een lastige discussie omdat vaak niet duidelijk is wat men bedoelt. Laten we het voor nu even zo definiëren: de internistenopleiding heeft een wetenschappelijk karakter als het voor de dagelijkse praktijk noodzakelijk is dat de aios gebruikt maakt van oorspronkelijke wetenschappelijk literatuur, en dat hij daar althans deels ook zelf een kritisch oordeel over moet kunnen vellen. Veel wetenschappelijk sterke collegae hebben nu al duidelijk de neiging deze vraag ontkennend te beantwoorden: neen, dat leren onze aios niet en dus is het geen wetenschappelijk opleiding. Mijns inziens zou een belangrijk gevolg hiervan kunnen zijn dat we veel minder dan nu in staat zullen blijken heel goede scholieren en studenten voor ons vak te interesseren, omdat wetenschap voor hen vaak een aantrekkelijke kant is van het specialistenvak. Bovendien zal het voor het niveau van de klinische geneeskunde in Nederland misschien wel niet zo goed zijn als de specialist van de toekomst niet meer het knapste meisje of jongetje van de klas is.

De toenemende aandacht voor opleiden gaat gepaard met de neiging opleiding en het doen van directe patiëntenzorg door de aios minder sterk aan elkaar te koppelen. Lees: minder directe patiëntenzorg te laten doen door de aios. Om u een voorbeeld te geven: aios moeten erg vaak allerlei cursussen doen, en zijn dan niet met patiënten bezig. Deze cursussen worden gegeven in de bona fide overtuiging dat als je maar een paar dagen in Utrecht in een zaaltje met gedimd licht hebt zitten luisteren naar goede sprekers, en ook een paar oefeningen hebt gedaan, dat je dan wel in je eigen ziekenhuis beter zult functioneren. Bewijs is er hiervoor helaas niet. Omdat er ontzettend veel geleerd moet 
worden door aios, neemt het aantal dagen te Utrecht van lieverlede sterk toe. Veel vooraanstaande Noord-Amerikaanse collega's die zich met opleiding bezig houden vinden nu al dat je in Europa eigenlijk geen goede specialist kunt opleiden, omdat je in een werkweek van circa 45 uur niet voldoende patiënten kunt zien. Als van die uren nog heel veel zaaltjes met gedimd licht af gaan krijgen zij natuurlijk steeds meer gelijk. Het onafwendbare gevolg zal zijn dat er een neiging tot sterkere specialisatie zal ontstaan: als 6 jaar te kort is om een allround internist te worden, nou laten we die 6 jaar dan maar gebruiken om een deel van de interne geneeskunde te leren. Dit zou in mijn ogen een wel heel kwalijk en negatief gevolg zijn, omdat de patiënt van de toekomst een brede dokter nodig heeft, en niet een baaierd van superspecialisten die elkaar nauwelijks meer begrijpen.

We zullen de komende jaren steeds meer te maken krijgen met concurrentie tussen opleidingen onderling. Professionalisering van opleidingen zal er zoals ik $u$ reeds zei toe leiden dat een aantal specialisten zich hier in belangrijke mate of zelfs voltijds mee zal gaan bezighouden. Deze collegae zullen een zekere mate van onderlinge concurrentie gaan voelen. 'Wij zijn toch echt de beste', gaan zij denken en zij zullen dit uitdragen. Kwaliteit van opleidingen is echter in objectieve zin voorlopig nog moeilijk tot niet meetbaar. Deze twee feiten gecombineerd zullen leiden tot enigszins potsierlijke pogingen alles wat zich daar maar enigszins toe leent uit zijn verband te rukken en als PR te gebruiken. Een geestig voorbeeld van het laatste wil ik $u$ niet onthouden. Elke 5 jaar visiteert de vereniging van Nederlandse universiteiten VSNU de 8 medische opleidingen. De laatste keer in 2003 werd afgesloten met de feestelijke presentatie van het eindrapport. De voorzitter van de visitatiecommissie zei toen dat er weliswaar cijfers gegeven werden, maar hij zei en toonde ter plekke aan dat die ongeschikt waren voor onderlinge vergelijking. Alle aanwezigen applaudisseerden en betuigden hun instemming. Dezelfde avond nog ging ieder van de 8 universiteiten aan de slag om de cijfers zo te interpreteren dat zij zichzelf tot 'winnaar' konden uitroepen. En aldus geschiedde: 1 van de 8 had al meteen de volgende ochtend een paginagrote advertentie in een landelijk dagblad waarmee dit UMC zich tot winnaar uitriep. De anderen volgden successievelijk. Nu zou dit alles onschuldig zijn ware het niet zo dat onze overheid het voornemen heeft uitgesproken deze onderlinge concurrentie te bevorderen. Men is voornemens benchmarks (dat wil zeggen normen die onderlinge vergelijking mogelijk maken) op te stellen, en men wil opleidingen daarop gaan afrekenen. Een gevolg 
zal uiteraard zijn dat de specialistenopleidingen zich niet zozeer druk gaan maken over de kwaliteit op zich, maar uit puur lijfsbehoud zullen zij vooral gaan proberen de benchmarks te halen. In dit verband is een interessante parallel te trekken met het in 2003 getekende Nationaal Politie Convenant. De minister tekende toen met de korpsbeheerders een contract waarin laatstgenoemden zich verplichtten de criminaliteit met $20 \%$ te verminderen. Een benchmark was onder andere het aantal uitgedeelde bekeuringen, en - voila - het aantal bekeuringen voor triviale overtredingen nam toe, vermoedelijk ten koste van daadwerkelijke misdaadpreventie.

Het zal u duidelijk zijn dat de verwachtingen omtrent vernieuwingen in medisch opleidingsland op dit moment erg hoog gespannen zijn, zo hoog dat het moeilijk zal zijn over enkele jaren niet teleurgesteld te raken. Tegelijkertijd wordt er nu in de media bijzonder veel aandacht besteed aan daadwerkelijk bestaande en vermeende misstanden in de specialistische gezondheidszorg. Er leeft dus nogal breed, zowel bij veel medici als bij het publiek, een gevoel dat het in de komende jaren 'allemaal heel veel beter zal worden'. Ik heb dit laatste bewust tussen aanhalingstekens gezet. Het is een nogal vaag omschreven gevoel, en naar mijn stellige mening hebben die twee dingen niets met elkaar te maken. Ik vind onze Nederlandse gezondheidszorg en met name het aandeel van de medisch-specialisten daarin persoonlijk van hoog en goed niveau. Daarin word ik gesteund door het recente NIVEL rapport: 'onbedoelde schade in Nederlandse ziekenhuizen' [6]. Hiervoor heeft men een zeer uitgebreid dossieronderzoek gedaan in Nederlandse ziekenhuizen, waarbij bleek dat 2,3\% van alle opgenomen patiënten te maken heeft met onbedoelde, en mogelijk vermijdbare schade. Dit betekent dat de patiënt ziek of zieker is geworden door de ziekenhuisopname. Van alle in het ziekenhuis overleden patiënten komt 4,1\% van de patiënten te overlijden door een onbedoelde, mogelijk vermijdbare gebeurtenis. Deze cijfers hebben veel stof doen opwaaien. Los van het feit of het waar is, blijken ze in vergelijking met vrijwel alle vergelijkbare buitenlandse cijfers gunstig af te steken. Dit is natuurlijk geen reden om stil te zitten, nee ik hoop dat ik $u$ heb overtuigd dat we wat moeten doen. Maar hoewel het altijd beter kan, en hoewel we met de tijd mee moeten gaan, et cetera, zoals ik u net verteld heb, verwacht ik persoonlijk niet dat wij over 10 tot 20 jaar met afgrijzen zullen terugdenken aan 2007. We zullen in komende jaren hoogstens te maken krijgen met een geleidelijke evolutie van onze specialistische gezondheidszorg, revolutionaire veranderingen zijn niet verwachten. 


\section{Verrassende en soms ernstige gevolgen van een excellente internisten- opleiding}

Als mijn laatste punt wil ik dan nu met u de volgende vraag onderzoeken: wat zijn de te verwachten gevolgen van het inrichten van een excellente internistenopleiding? Het is natuurlijk een wat rare vraag. De aanwezige collega-opleiders en de aios denken uiteraard onmiddellijk: een verrassend gevolg is als elke aios van mijn opleiding een baan krijgt na zijn opleiding, en een ernstig gevolg zou zijn als de aios allemaal werkloos zouden blijven. lets verder denkend is voor hen een verrassend gevolg als de aios 10 jaar na het einde van hun opleiding een baan hebben waar ze blij en gelukkig mee zijn, ernstig zou zijn als zij dan allen afgeknapt zouden zijn op het vak. Maar hoewel deze 'gevolgen' ontegenzeggelijk van belang zijn, wil ik toch nog iets verder kijken.

Willen we verder komen dan moeten we de vraag dus wat scherper gaan stellen. Dat leren we immers ook aan onze aios. Een aios zou zich bijvoorbeeld over een patiënt de vraag kunnen stellen: 'moet je een colonoscopie (inwendig onderzoek van de dikke darm) doen bij een jonge vrouw met bloedarmoede zonder duidelijke oorzaak'. Dat lijkt een beetje vaag, en beter is om zo'n vraag te specificeren volgens het PICOsysteem: patiënt of probleem, interventie, vergelijking (in het Engels is dat comparison), outcome. Dus: als een jonge vrouw met bloedarmoede door ijzergebrek komt waarvoor geen duidelijke oorzaak aanwezig is, wat is dan de invloed van een inwendig onderzoek van de dikke darm (coloscopie), in vergelijking met geen verder onderzoek doen, op haar kans om te overlijden in de komende 5 jaar. Deze PICO's leiden tot levendige debatten, die vaak gaan over wat een relevante uitkomst is. Zoiets moeten we ook doen voor de internistenopleiding. We maken een PICO!

Ons probleem is uiteraard de internistenopleiding. De interventie is deze excellent maken, en de vergelijking is niets doen, dus deze opleiding zo laten als ze is. De interventie is heel erg veel werk: het opleidingsteam wordt samengesteld uit vooraanstaande wetenschappers, uit specialisten die gepokt en gemazeld zijn als trainer-coach, en uit heel goede rolmodellen. Zij leiden breed georiënteerde internisten op die als medicus op zich weer vooraanstaand zijn, die ver over de grenzen van het vak heen kijken, en die uitstekende teamleden zijn. Het gehele ziekenhuis waar de opleiding plaats vindt is op opleiden ingericht. Deze interventie realiseren is een tour-de-force par-excellence. Er moeten dus spectaculaire gevolgen voortvloeien uit deze interventie, anders moeten 
we er maar niet aan beginnen. Het is naar mijn mening jammer dat het bedenken van uitkomsten meestal uitmondt in gemeenplaatsen, zoals 'een medisch-inhoudelijk goede, professioneel handelende dokter, die goed samenwerkt ...' etcetera, u kunt de rest wel bedenken. Wij weten allen dat een dergelijke dokter (wellicht moeten we spreken van een heilige) niet bestaat, nooit zal bestaan, en dat we het bezitten van zulke kwalificaties nooit zullen kunnen meten. Dergelijke uitkomstonderzoeken zijn dan ook niet gedaan, ze kunnen niet eens worden opgezet.

De gevolgen van de excellente internistenopleiding zitten wat mij betreft vooral in de interventie zelf. Om deze specialist op te leiden zal ik mijn ziekenhuis als organisatie sterk moeten gaan veranderen. Zoals ik $u$ geschetst heb is de manier waarop de aios zijn werk doet sinds begin jaren 80 van de vorige eeuw sterk veranderd. De aios werkt nu in een team (of ploeg), en de werkdruk van dat team is hoog. De leden van deze teams zijn sterk van elkaar afhankelijk. Deze teams moeten dus als zodanig getraind worden, en bijvoorbeeld het functioneren van een aios als individu - hoewel belangrijk - zal steeds meer plaats moeten maken voor het functioneren van het team. Bovendien zullen deze teams in toenemende mate buiten de grenzen van hun traditionele specialisme moeten gaan opereren. Dit vereist een samenstelling die multidisciplinair is. Bovendien zullen met name de generalistische vaardigheden van de specialist moeten worden ontwikkeld, ten kost van de superspecialistische. Het is nog volstrekt onduidelijk hoe, want er zijn hiervoor nog geen onderwijsmethoden. Deze teams zijn overigens in belangrijke mate buiten de befaamde 'kantooruren' actief, omdat de week nu eenmaal 168 uur telt, waarvan slechts circa 40 uur kantoortijden. De opleidingsmomenten zullen dus ook veel meer dan nu buiten kantooruren moeten gaan plaatsvinden. De specialisten zullen bereid moeten zijn 's avonds en 's nachts naar het ziekenhuis te komen, of zelfs in het ziekenhuis te blijven, voor de opleiding. Er zullen onderwijsmethoden moeten worden ontwikkeld om alle leren op de werkvloer plaats te laten vinden, dus tijdens het doen van patiëntenzorg. De cursussen, die nu nog bij gedimd licht te Utrecht plaatsvinden, worden grotendeels afgeschaft. Alle opleiders zullen als rolmodel moeten functioneren, en dus altijd voorbeeldgedrag moeten vertonen, en zij niet alleen, maar ook de verpleegkundige, en de directeur bijvoorbeeld. Het opleidingsziekenhuis moet de ambitie hebben de bestmogelijke patiëntenzorg te leveren, en heeft daarom een permanente verbetercultuur. Deze dingen: teamwork, multidisciplinair werken, generalisme, leren op de werkvloer, voorbeeldgedrag, een 
verbetercultuur, en de ambitie om de allerbeste patiëntenzorg te leveren, zij zijn zowel de excellente internistenopleiding zelf, als de belangrijkste gevolgen van de excellente internistenopleiding. Als het ons lukt dat te realiseren zullen wij allen, patiënten, dokters, en andere medewerkers, verrast zijn. Dat deze gevolgen ernstig zijn zal blijken uit de enorme en permanente inspanning die nodig is om zover te komen. We hoeven echter op deze 'gevolgen' niet lang te wachten, ze zijn op korte termijn realiseerbaar en heel concreet.

\section{Maastrichtse plannen}

De universiteit Maastricht dankt haar bekendheid voor een belangrijk deel aan haar PGO-systeem, en dat staat - zoals bekend - voor Probleem Gestuurd Onderwijs. De student stuurt zelf zijn studie aan de hand van problemen uit de praktijk. Begin jaren 70 van de vorige eeuw was dat systeem revolutionair en nieuw. Elders was men er nog niet zo van overtuigd dat je met dit systeem, dat de student - en niet de docent centraal stelt, een goede dokter kunt opleiden. De Universiteit Maastricht heeft om die reden onderwijskundig onderzoek altijd gestimuleerd. Inmiddels is uit voor een belangrijk deel in Maastricht uitgevoerd onderzoek duidelijk geworden dat de via PGO opgeleide basisarts een goede dokter is die met name op het gebied van sociale vaardigheden zijn traditioneel opgeleide collega's de loef afsteekt, en die door zijn enthousiasme en plezier in de studie veel sneller studeert dan elders.

De tijd is nu gekomen om met de voor de Universiteit Maastricht kenmerkende vernieuwingsdrang, gecombineerd met de hier aanwezige uitzonderlijkeonderwijskundige expertise, te gaan werken aan het maken van excellente specialistenopleidingen. Hiervoor wordt op dit moment in snel tempo een zeer interessant regionaal samenwerkingsverband opgezet. Universiteit en Academisch Ziekenhuis Maastricht hebben zich hiervoor verenigd met de ziekenhuizen van Limburg en Zuidoost Brabant in de OORZON: Opleidings en Onderwijs Regio Zuid-Oost Nederland. In deze regio zijn circa 600 artsen in opleiding tot specialist. De ambitie van deze regio is hun opleiding excellent te maken en er zo voor te zorgen dat zij vooraanstaande specialisten worden. Een dergelijk ambitieus plan kan alleen verwezenlijkt worden via collegiale samenwerking tussen academische onderwijskundigen, en medisch specialisten van zowel niet-academische ziekenhuizen als het academisch ziekenhuis.

De plannen verbonden aan mijn leerstoel om een excellente internistenopleiding te maken kunnen geen betere voedingsbodem 
vinden dan OORZON. Deze plannen vallen onder 3 thema's. Allereerst het ontwikkelen van leren op de werkvloer. Hieronder valt het inrichten van de ziekenhuis-afdelingen als werkplek die het leren faciliteert: effectieve methoden uit de literatuur zullen worden gebruikt om dit in het AzM en de regioziekenhuizen te verwezenlijken. Nieuwe methoden zullen worden opgezet om aios te laten leren van incidenten en fouten die in het ziekenhuis nu eenmaal optreden. De tweede groep plannen betreft het bevorderen van generalisme, teamwork en samenwerking. Hoe organiseren we als specialisten ons werk zo in dat de patiënt met een dokter te maken heeft die over de grenzen van zijn beperkte domein heen blijft kijken. Het is mijn stellige overtuiging dat de algemeen internist hierin een centrale plaats heeft en dat we die moeten versterken. Ten derde moeten we modellen ontwikkelen om specialisten zo op te leiden tot klinisch onderzoekers dat goede patiëntenzorg hand in hand gaat met goed onderzoek, maar zodanig dat heel goede patiëntenzorg altijd voorop blijft staan.

\section{Dankwoord}

Tenslotte wil ik een aantal mensen bedanken. Allereerst de vele aios en studenten die ik in mijn loopbaan ben tegengekomen. Van hen heb ik veel geleerd en aan het bezigzijn met hun opleiding heb ik altijd het meeste plezier in mijn werk ontleend. Veel dank ben ik verschuldigd aan mijn opleiders. Achtereen noem ik Johan Vreeken, Tontin van Leeuwen en Bert Arisz, allen hoogleraar interne geneeskunde aan de Universiteit van Amsterdam, nu emeriti. Wat ik in hen zo heb gewaardeerd is dat zij niet alleen uitstekende internisten waren. Zij combineerden dit met persoonlijke aandacht voor hun aios, een brede en kritische blik op alles wat er in een ziekenhuis gebeurde, een blik die veel verder ging dan het puur medische. Tegen hen keek en kijk ik op, en zij waren mijn voorbeelden. De Universiteit van Amsterdam, het Wilhelminagasthuis en het Binnengasthuis, later het AMC, dat zijn de plaatsen waar ik het vak heb geleerd. In mijn ogen nog steeds een van de beste plaatsen om dokter en internist te worden, door het vanoudsher sterk didactisch onderwijs, vanaf dag 1 met echte patiënten, gecombineerd met een sterke wetenschappelijke traditie. Heel bijzonder dat prof Ernest Briet, als Leidse hematoloog, die traditie heeft kunnen voortzetten en uitbouwen. Aan hem en dr Wouter Wieling heb ik erg veel te danken, omdat zij mij op uitnodigende en enthousiasmerende wijze op dit pad hebben gezet dat uiteindelijk hier in Maastricht is uitgekomen. Dat laatste dank ik 
aan prof Coen Stehouwer. Beste Coen, je hebt grote ambitie en een heel duidelijk beeld van de toekomst van de interne geneeskunde. Daarin gaan opleiden, patiëntenzorg en wetenschap niet alleen samen, maar de drie typisch academische taken hebben elkaar nodig en maken een som die veel groter is dan de delen. Ik verwacht en hoop dat we de komende jaren die ambitie hier in Maastricht kunnen realiseren; hier in Maastricht, waar de unieke combinatie is van een wetenschappelijk topinstituut, een universiteit die onderwijs en opleiden als kerntaak ziet, en een Academisch Ziekenhuis dat het mogelijk maakt om zowel 'gewone' als gespecialiseerde patiëntenzorg te leren.

Ik zou hier op deze manier niet staan zonder de ondersteuning van mijn vader en moeder. Jullie hebben me nooit in enige richting geduwd, maar waren altijd geïnteresseerd in -, en enthousiast over dat wat ik deed. Jullie humor, en jullie relativerende kijk op het leven zijn nog altijd een grote steun voor mij. De manier waarop jullie naar dokters kijken en over ze praten is voor mij maatgevend.

Felix, Renate en Annette: naar Maastricht was een onvoorstelbare stap. Dat wij die stap samen gemaakt hebben maakt dat het hier leuk is. Van jullie houd ik, en daarom ben ik er van overtuigd dat het hier almaar leuker gaat worden.

Ik heb gezegd. 


\section{Noten}

1. Ericsson KA. Deliberate practice and the acquisition and maintenance of expert performance in medicine and related domains. Acad Med. 2004;79:570-81.

2. to practice betekent in het Engels zowel praktizeren (praktijk uitoefenen) als oefenen. Beide betekenissen zijn relevant bij een vertaling van deliberate practice

3. Wright SM, Kern DE, Kolodner K, Howard DM, Brancati FL. Attributes of excellent attending-physician role models. N Engl J Med 1998;339:1986-93

4. de ziekte AIDS werd voor het eerst beschreven in 1981 (en de naam kwam pas later), hoewel men sindsdien heeft vastgesteld dat er al eerder in de $20^{\mathrm{e}}$ eeuw mensen aan gestorven zijn

5. Heijden, FMMA vd, e.a. Burnout in de opleiding tot medisch specialist. Medisch Contact 25 november 2005, p 1904-7

6. Onbedoelde schade in Nederlandse ziekenhuizen; dossieronderzoek van ziekenhuisopnames in 2004. MC De Bruijne e.a., NIVEL/EMGO 2007. 
